\title{
PILATES EFFECTS ON SPINAL COLUMN POSTURAL STATUS: A SYSTEMATIC REVIEW
}

\author{
Bojan Jorgic, Katarina Petrović, \\ Saša Milenković, Dobrica Živković \\ University of Nis, Serbia
}

\begin{abstract}
:
Pilates exercise programs focus on increasing the strength and flexibility of muscles which make up core stability. Since the same muscles take part in maintaining proper posture, the aim of this study was to provide an overview of the existing research in order to determine the effects of a pilates exercise program on the improvement of postural status. When searching electronic databases, the following key words were used: spine, posture, effect, pilates, kyphosis, scoliosis, lordosis. Based on the set criteria, that the research was published after 2010 and that the applied pilates exercise programs focused on correcting postural status, the final analysis included 10 studies. An analysis of the characteristics of the sample of participants indicates that the problem of postural disorders is equally present among individuals of various ages. In terms of gender, in the analyzed studies the female population was almost four times the size of the male population. In most of the studies the exercise program lasted for 8 and 12 weeks, with 2 to 3 training sessions per week, with a duration of $60 \mathrm{~min}$. Eight of the analyzed studies show that pilates exercise programs led to an improvement in the postural status. Based on the extensive analysis, it can be concluded that pilates has positive effects on the correction of postural disorders of the spinal column, such as kyphosis, lordosis and scoliosis among people of different ages.
\end{abstract}

Key words: corrective exercise, scoliosis, lordosis, kyphosis

\section{Introduction}

Proper posture represents the correct positioning of segments of the body (muscles, ligaments and bone tissue) whose role it is to, with the lowest possible expenditure of energy, enable its maintenance (Jovović, 2008). Deviation from proper posture or any disturbances of the postural status require a greater expenditure of energy and lead to the limited movement of the particular segment where the problem is located (Sabo, 2006; Milenković, 2007). The side-effects which emerge as a result of external and internal factors can cause a disturbance of the postural status of the spinal column (Jovović, 2008). The postural disorders of the spinal column occur in the frontal and sagittal plane, and can be noted based on convexity which can be directed towards the inside (lordotic posture) or outwards (kyphotic posture) or can be external that is directed either toward one or the other side of the frontal plane (scoliotic posture) (Živković, 2000; Milenković, 2007). Corrective exercise programs are meant to, with the help of proper dosing of physical exercise, correct any disorders of the postural status of the spinal column (Živković, 2009; Jovović, 2008). One of these programs which could be used is pilates, which was designed by Joseph Pilates in the first half of the twentieth centu- ry, and which represents a combination of various physical exercise programs with the sole goal of establishing muscle balance based on strength of mind (Šiler, 2005; Krejg, 2005; Wells et al., 2012; Cvetković et al., 2008). With the proper selection of exercises with controlled dosing, pilates programs can influence the correction of postural disorders of the spinal column (Nikolov, 2014). Their goal is to establish a balance between the muscle strength of the entire body and to maintain their harmonious synchronicity. Pilates exercise programs focus on increasing the strength and flexibility of muscles which make up core stability. Since the same muscles take part in maintaining proper posture, the aim of this study was to provide an overview of the existing research to determine the effects of a pilates exercise programs on the improvement of postural status.

\section{Methodology}

In order to analyze the existing studies, we used the following electronic databases: Google Scholar, SCIndeks, MEDLINE, SPORTDiscus, PubMed and Web of Science. When searching the databases we used the following key words: Correct posture of spine, posture of spine, effect pilates exercises, kyphosis, scoliosis, lordosis. The identified titles of the 
studies, abstracts and entire texts were analyzed and selected based on the following criteria: whether the studies were published during the period between 2010 and 2016, whether the participants were diagnosed with postural status disorders of the spinal column, and whether the participants were subjected to a pilates exercise program focused on the correction of the postural status of the spinal column.

The studies which met the set criteria were then analyzed and presented based on the following parameters: references (the first letter of the author's name and the year of publication), the sample of participants (the number of participants, age of the participants, gender of the participants and the number of groups of participants), the experimental treatment, monitored parameters, measuring instruments and the research results

\section{Results}

Compiling the research, the analysis of the individual papers and their selection is shown in figure 1 . After various levels of selection, it was determined that 11 papers met the set criteria and what ensued was their detailed analysis.

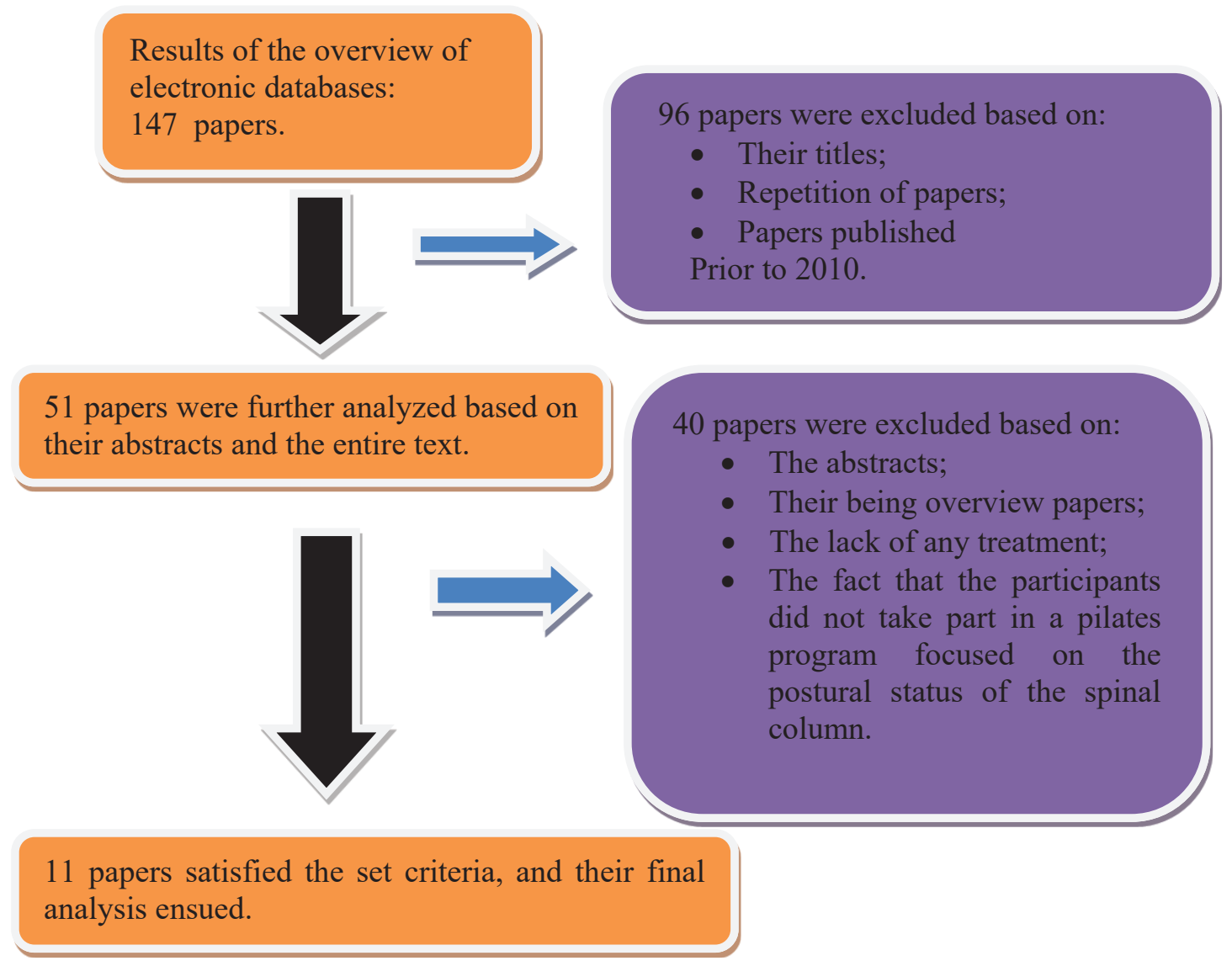

Figure 1. The analysis procedure of the selected papers

The results of the analyzed studies are shown in table 1. Starting from 2010, most of the papers on the topic of the effects of pilates exercise programs on postural status was published in 2016, while from 2011 to 2015 no papers of this type were published. In terms of the number of participants, the smallest number of participants were found in the work of Emery et al. (2010) while the largest number of participants $(n=50)$ were included in the work of Kloubec et al. (2010). In eight papers the samples of participants were divided into an experimental group and a control group, while in one paper the participants were divided into two experimental groups (Kim et al., 2016), and in yet another there was only one experimental group (Krawczky et al., 2016). 
Table 1. An overview of the compiled and analyzed studies

\begin{tabular}{|c|c|c|c|c|c|c|c|c|}
\hline $\begin{array}{lllll}\mathrm{F} & \mathrm{I} & \mathrm{R} & \mathrm{S} & \mathrm{T}\end{array}$ & SAMPLE O & $\overline{\text { F PART }}$ & ICIPANTS & EXPERIMENTAL T & REATMEN & & & \\
\hline $\begin{array}{l}\text { AU T HOR } \\
\text { AND YEAR }\end{array}$ & Number & $\begin{array}{l}\text { Ge } n- \\
\text { der }\end{array}$ & Year & Program & Duration & \begin{tabular}{|l} 
Measuring instru- \\
ment
\end{tabular} & Outcomes & RESULTS \\
\hline $\begin{array}{l}\text { Emery, } \\
2010 .\end{array}$ & $\begin{array}{l}n=19 ; \\
1 E(n=10) \\
1 K(n=9)\end{array}$ & $\mathrm{M} / \mathrm{F}$ & $\begin{array}{l}\mathrm{E}( \pm 33.1 \\
8.6) \\
\mathrm{K}( \pm 28.6 \\
3.7)\end{array}$ & $\begin{array}{l}\text { Pilates (exercises } \\
\text { for strengthening } \\
\text { abdominal muscu- } \\
\text { lature) }\end{array}$ & $\begin{array}{l}\mathrm{UT}^{\prime}=12 \\
\text { weeks; } \\
\mathrm{NU}=2 ; \\
\mathrm{TT}=60 \\
\text { minutes. }\end{array}$ & $\begin{array}{l}\text { Vicon } 512 \text { Motion } \\
\text { Analysis System, }\end{array}$ & $\begin{array}{l}\text { The angle } \\
\text { of kyphosis } \\
\text { measured in a } \\
\text { seated position }\end{array}$ & $\begin{array}{l}1 \mathrm{E} \text { : sig. } 囚 \text { decrease in } \\
\text { kyphosis measures } \\
\text { at rest in a seated } \\
\text { position }\end{array}$ \\
\hline $\begin{array}{l}\text { Kloubec } \\
2010 .\end{array}$ & $\begin{array}{l}n=50 ; \\
1 E(n=25), \\
1 K(n=25)\end{array}$ & $\mathrm{M} / \mathrm{F}$ & $\begin{array}{l}\text { E (58-26); } \\
\text { K (30-59) }\end{array}$ & $\begin{array}{l}\text { Pilates (exercises for } \\
\text { muscle endurance } \\
\text { and flexibility of the } \\
\text { abdomen) }\end{array}$ & $\begin{array}{l}\mathrm{UT}=12 \\
\text { weeks; } \\
\mathrm{NU}=2 ; \\
\mathrm{TT}=60 \\
\text { minutes }\end{array}$ & $\begin{array}{l}\text { A coordinate network } \\
\text { for the postural } \\
\text { analysis. }\end{array}$ & Postural status & $\begin{array}{l}\text { No significant } \\
\text { differences were } \\
\text { determined between } \\
\text { groups in terms of } \\
\text { postural status. }\end{array}$ \\
\hline $\begin{array}{l}\text { De Araújo, } \\
2012 .\end{array}$ & $\begin{array}{l}n=31 ; \\
1 E(n=20), \\
1 K(n=11)\end{array}$ & $F$ & $18-25$ & $\begin{array}{l}\text { Pilates (exercises for } \\
\text { muscle endurance } \\
\text { and flexibility with } \\
\text { the help of props) }\end{array}$ & $\begin{array}{l}\mathrm{UT}=36 \\
\text { weeks; } \\
\mathrm{NU}=2 ; \\
\mathrm{TT}=60 \\
\text { minutes. }\end{array}$ & $\begin{array}{l}\text { Adam's test, a radio- } \\
\text { graphic method and } \\
\text { Cobb's angle }\end{array}$ & $\begin{array}{l}\text { Angle of the } \\
\text { dorsal lumbar } \\
\text { scoliosis. }\end{array}$ & $\begin{array}{l}\text { 1E: sig. 冈angle of } \\
\text { scoliosis }\end{array}$ \\
\hline $\begin{array}{l}\text { Junges, } \\
2012 .\end{array}$ & $\begin{array}{l}n=41 \\
1 E(n=22) \\
1 K(n=19\end{array}$ & $\mathrm{F}$ & Mean 59 \pm 9 & $\begin{array}{l}\text { Pilates (basic deep } \\
\text { breathing exercises } \\
\text { and strength and } \\
\text { stretching exercises) }\end{array}$ & $\begin{array}{l}\mathrm{UT}=30 \\
\text { weeks; } \\
\mathrm{NU}=2 ; \\
\mathrm{TT}=60 \\
\text { minutes. }\end{array}$ & $\begin{array}{l}\text { Cobb's angle, Fisimet- } \\
\text { rix program }\end{array}$ & $\begin{array}{l}\text { The angle of ky- } \\
\text { phosis, postural } \\
\text { status }\end{array}$ & $\begin{array}{l}\text { 1E: sig. } \otimes \text { angle of } \\
\text { kyphosis; sig.* } \\
\text { postural status }\end{array}$ \\
\hline $\begin{array}{l}\text { Rezaei, } \\
2014 .\end{array}$ & $\begin{array}{l}n=30 \\
1 E(n=15) \\
1 K(n=15)\end{array}$ & $F$ & $\begin{array}{l}\mathrm{E}( \pm 28.86 \\
4.75) \\
\mathrm{K}( \pm 28.2 \\
4.68)\end{array}$ & $\begin{array}{l}\text { Pilates (strength } \\
\text { and flexibility } \\
\text { exercises) }\end{array}$ & $\begin{array}{l}\mathrm{UT}=8 \\
\text { weeks; } \\
\mathrm{NU}=3 ; \\
\mathrm{TT}=60 \\
\text { minutes }\end{array}$ & A flexible ruler & $\begin{array}{l}\text { Lumbar lor- } \\
\text { dosis }\end{array}$ & $\begin{array}{l}\text { 1E: sig. 冈angle of } \\
\text { lordosis }\end{array}$ \\
\hline $\begin{array}{l}\text { Sinzato, } \\
2013 .\end{array}$ & $\begin{array}{l}n=33 \\
1 E(n=14) \\
1 K(n=19)\end{array}$ & $\mathrm{F}$ & $18-30$ & $\begin{array}{l}\text { Pilates (strength } \\
\text { and flexibility } \\
\text { exercises) }\end{array}$ & $\begin{array}{l}\mathrm{UT}=10 \\
\text { weeks, } \\
\mathrm{NU}=2 ; \\
\mathrm{TT}=60 \\
\text { minutes }\end{array}$ & $\begin{array}{l}\text { Postural Assessment } \\
\text { software }\end{array}$ & Postural status & $\begin{array}{l}\text { No significant } \\
\text { differences were } \\
\text { determined between } \\
\text { groups in terms of } \\
\text { postural status. }\end{array}$ \\
\hline $\begin{array}{l}\text { Schroeder, } \\
2014 .\end{array}$ & $\begin{array}{l}\mathrm{n}=24 ; 1 \mathrm{E} \\
(\mathrm{n}=10) \\
1 \mathrm{~K}(\mathrm{n}=14)\end{array}$ & $F$ & $33-53$ & $\begin{array}{l}\text { Pilates (strength } \\
\text { and muscle flexibil- } \\
\text { ity exercises) }\end{array}$ & $\begin{array}{l}\mathrm{UT}=12 \\
\text { weeks; } \\
\mathrm{NU}=1 ; \\
\mathrm{TT}=60 \\
\text { minutes }\end{array}$ & $\begin{array}{l}\text { An analysis of the } \\
\text { spinal shapes (stereg- } \\
\text { oraphic algorithm) }\end{array}$ & $\begin{array}{l}\text { The angle of ky- } \\
\text { phosis, angle of } \\
\text { lordosis, pelvic } \\
\text { incline, length } \\
\text { of the spinal } \\
\text { column }\end{array}$ & $\begin{array}{l}\text { 1E: sig. 冈angle of } \\
\text { kyphosis, sig. } 囚 \\
\text { length of the spinal } \\
\text { column; no other } \\
\text { differences. }\end{array}$ \\
\hline Kim, 2016. & $\begin{array}{l}n=24 \\
1 E(n=12) \\
2 E(n=12)\end{array}$ & $F$ & $\begin{array}{l}1 \mathrm{E} \\
(\text { Mean } \pm \mathrm{SD} \\
=15.6 \pm \\
1.1) \\
\\
2 \mathrm{E}(\text { Mean }= \\
15.3 \pm 0.8)\end{array}$ & $\begin{array}{l}1 \mathrm{E}-\text { Schroth } \\
\text { exercises } \\
2 \mathrm{E}-\text { pilates (cor- } \\
\text { rective exercises, } \\
\text { exercises of strength } \\
\text { and bal }\end{array}$ & $\begin{array}{l}\mathrm{UT}=12 \\
\text { weeks; } \\
\mathrm{NU}=3 ; \\
\mathrm{TT}=60 \\
\text { minutes }\end{array}$ & $\begin{array}{l}\text { Radiography (Cobb's } \\
\text { angle) }\end{array}$ & $\begin{array}{l}\text { The angle of } \\
\text { scoliosis }\end{array}$ & $\begin{array}{l}\text { For both groups a } \\
\text { sig. } \bigotimes \text { decrease in the } \\
\text { angle of scoliosis } \\
\text { was noted, where } \\
\text { the improvement } \\
\text { was greater for the } \\
\text { 1E. }\end{array}$ \\
\hline $\begin{array}{l}\text { Krawczky, } \\
2016 .\end{array}$ & $1 \mathrm{E}(\mathrm{n}=13)$ & $\mathrm{M} / \mathrm{F}$ & $18-59$ & $\begin{array}{l}\text { Pilates (exercises } \\
\text { of flexibility and } \\
\text { strength) }\end{array}$ & $\begin{array}{l}\mathrm{UT}=8 \\
\text { weeks; } \\
\mathrm{NU}=2 ; \\
\mathrm{TT}=60 \\
\text { minutes }\end{array}$ & SAPO software & $\begin{array}{l}\text { The angle of ky- } \\
\text { phosis, lordosis, } \\
\text { the horizontal } \\
\text { position of the } \\
\text { head, pelvis) }\end{array}$ & $\begin{array}{l}\text { 1E: sig. } 囚 \text { a decrease } \\
\text { in the angle of ky- } \\
\text { phosis and lordosis }\end{array}$ \\
\hline $\begin{array}{l}\text { Navega, } \\
2016 .\end{array}$ & $\begin{array}{l}n=31 ; \\
1 E(n=14) \\
1 K(n=17)\end{array}$ & $\mathrm{F}$ & $60-75$ & $\begin{array}{l}\text { Pilates (exercises for } \\
\text { stretching muscles } \\
\text { and hips, and torso } \\
\text { stabilization) }\end{array}$ & $\begin{array}{l}\mathrm{UT}=8 \\
\text { weeks; } \\
\mathrm{NU}=2 . \\
\mathrm{TT}=60 \\
\text { minutes }\end{array}$ & biophotogrammetry & $\begin{array}{l}\text { The angle of } \\
\text { kyphosis }\end{array}$ & $\begin{array}{l}\text { 1E: sig. } \text {. decrease } \\
\text { in the angle of } \\
\text { kyphosis }\end{array}$ \\
\hline $\begin{array}{l}M-\text { male p } \\
\text { cally signifi } \\
\text { frequency; }\end{array}$ & cipant; & 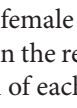 & divid & $\begin{array}{l}\text { - first experiment } \\
\text { atistically significa } \\
\text { ining session. }\end{array}$ & ductio & he results; UT - over & $\begin{array}{l}\text { dup; } 1 \mathrm{~K}-\text { contr } \\
\text { duration of the }\end{array}$ & $\begin{array}{l}\text { group; sig. } \uparrow \text { - statisti- } \\
\text { rogram; NU - weekly }\end{array}$ \\
\hline
\end{tabular}


In three of the ten studies, the sample of participants consisted of individuals of both genders (Emery et al., 2010; Kloubec et al., 2010; Krawczky et al., 2016) while in the remaining papers the samples of participants were made up of women. The youngest population (average age $=15$ ) included in a study was found in the work done by (Kim et al., 2016), while the oldest (60-75) was found in the work of Navega et al. (2016). In nine of the ten papers the experimental treatment that was used was only a pilates program, while in the work of Kim et al. (2016), in addition to a pilates program, the Schroth method was also used. The pilates exercise programs consisted of exercises performed without props and apparatuses, except in the work of De Araújo et al. (2012) which relied on theraband resistance bands, pilates balls and steppers. The exercises which were implemented had as a goal to increase flexibility and strength of the muscles. The duration of the exercise program lasted from at least 8 weeks in the studies (Rezei et al., 2014; Krawczky et al., 2016, Navega et al., 2016) up to 36 weeks in the work of De Araújo et al. (2012). In most of the studies the exercise programs lasted from 8 to 12 weeks. The weekly frequency was twice a week in seven studies, in two of the studies it was three times a week, while a frequency of only once a week was noted in the study of Schroeder et al. (2014). In all the studies the duration of an individual training session was 60 minutes. The studies monitored various parameters which refer to the postural status, as well as parameters which refer to postural disorders on the spinal column. That was why the angles of kyphosis, lordosis and scoliosis were measured, along with the horizontal positions of the head, the horizontal position of the pelvis, the angle of the hips, and the vertical position of the body. In eight of the ten studies the implemented programs of pilates exercises led to an improvement in the results, in the sense that there was a decrease in the angles of lordosis, kyphosis, scoliosis as well as positive changes in other measured parameters. Only in the works of Kloubec et al., (2010) and Sinzato et al. (2013) were no improvements noted in the measured parameters of postural status.

\section{Discussion}

Based on the year of publication of the analyzed papers, we can note that the research into the effects of the implementation of pilates programs on postural status is very current, since it is precisely in 2016 that most of the papers were published. In the case of the gender of the participants involved in the pilates programs for the correction of postural disorders, there were almost four time as many women as men. This gives us room to study the effects of the pilates program on the correction of postural disorders among male participants, considering the gender differences in the motor skills. When it comes to the age of the participants, we can note that the problem of postural disorders is equally present among participants, irrespective of age, from adolescence to old age, where most of the analyzed cases involved a population with an average age of 20 to 65 . Compared to postural disorders, we can say that most of the participants showed signs of the changes in postural status located on the frontal plane (scoliosis) and on the sagittal plane (kyphosis and lordosis). Based on the analysis of the overall program duration, and the weekly frequency of duration of individual training sessions, we can conclude that the pilates programs which lasted from 8 to 12 weeks with a weekly frequency of two or three times a week, and sixty-minute training sessions, have positive effects on the correction of postural disorders of the spinal column. This kind of information is significant because it indicates that postural disorders can be corrected by implementing pilates exercise programs over a relatively short period of time of 2 to 3 months, which can certainly have a positive effect on people with this condition, influencing them to opt for this corrective exercise program.

\section{Conclusion}

Based on the extensive analysis, it can be conclude that pilates programs which last from 8 to 12 weeks, with a weekly frequency of 2 to 3 times a week, with a minimum duration of individual training sessions of 60 min have positive effects on the correction of postural disorders of the spinal column, such as kyphosis, lordosis and scoliosis among people of different ages.

\section{References}

Cvetković, M., Obradović, J. and Kalajdžić, J. (2008), Efekti pilatesa na morfološke karakteristike studentkinja fakulteta fizičke culture[The effects of pilates on the morphological characteristics of female physical education students] Glasnik Antropološkog društva Srbije, 43, 605-613.

De Araújo, M. E. A., da Silva, E. B., Mello, D. B., Cader, S. A., Salgado, A. S. I. and Dantas, E. H. M. (2012). The effectiveness of the Pilates method: reducing the degree of non-structural scoliosis, and improving flexibility and 
pain in female college students, Journal of bodywork and movement therapies, 16(2), 191-198.

Emery, K., De Serres, S. J., McMillan, A. and Côté, J. N. (2010), The effects of a Pilates training program on armtrunk posture and movement, Clinical Biomechanics, 25(2), 124-130.

Jovović, V. (2008), Korektivna gimnastika sa kineziterapijom. [Corrective gymnastics with kinesitherapy] Filozofski fakultet, Nikšić.

Junges, S., Gottlieb, M. G., Baptista, R. R., Quadros, C. B. D., Resende, T. D. L. and Gomes, I. (2012), Effectiveness of pilates method for the posture and flexibility of women with hyperkyphosis. Rev Bras Cienc Mov, 20(1), 21-33.

Kim, G. and HwangBo, P. N. (2016), Effects of Schroth and Pilates exercises on the Cobb angle and weight distribution of patients with scoliosis, Journal of physical therapy science, 28(3), 1012-1015.

Kloubec, J. A. (2010), Pilates for improvement of muscle endurance, flexibility, balance, and posture, The Journal of Strength \& Conditioning Research, 24(3), 661-667.

Krawczky, B., Mainenti, M. R. M. and Pacheco, A. G. F. (2016), The impact of pilates exercises on the postural alignment of healthy adults, Revista Brasileira de Medicina do Esporte, 22(6), 485-490.

Krejg, K. (2005), Pilates na lopti. [Pilates on a ball] Luka Štampa, Beograd.

Milenković, S. (2007), Korektivna gimnastika, teorija $i$ vezbe [Corrective gymnastics, theory and practice]. SIA, Niš

Navega, M. T., Furlanetto, M. G., Lorenzo, D. M., Morcelli, M. H. and Tozim, B. M. (2016). Effect of the Mat Pilates method on postural balance and thoracic hyperkyphosis among elderly women: a randomized controlled trial, Revista Brasileira de Geriatria e Gerontologia, 19(3), 465-472.

Nikolov, M. (2014), Uloga pilates vežbi u kondicijskoj pripremi sportista [The role of pilates in the fitness training of athletes], Bachelor's thesis, Fakultet sporta i fizičkog vaspitanja, Beograd.

Sabo, E. (2006), Posturalni status dece predskolskog uzrasta na teritoriji AP Vojvodine [Postural status of preschool children on the territory of the AP Vojvodina], Fizička kultura, 60(2), 157-164.

Rezaei, A., Mahdavinejad, R. and Rezaei, S.S. (2014), Pilate's selected exercises effects on women's lumbar hyperlordosis in immediate post-partum period, Asian Journal of Multidisciplinary Studies, 2(2), 48-53.

Schroeder, J., Grenz, K., Schaar, H., Liebig, M. and Braumann, K. M. (2014), Pilates Can Affect Sagittal Spinal Alignment: An Observational Study, J Spine, 3(180), 2.

Sinzato, C. R., Taciro, C., Pio, C. D. A., Toledo, A. M. D., Cardoso, J. R. and Carregaro, R. L. (2013), Effects of 20 sessions of Pilates method on postural alignment and flexibility of young women: pilot study. Fisioterapia e Pesquisa, 20(2), 143-150.

Šiler, B. (2005), Pilates telo [Pilates body], Akademska štampa, Beograd.

Wells, C., Kolt, S.G. and Bialocerkowski, A. (2012), Defining Pilates exercise: A systematic review, Complementary Therapies in Medicine, 20, 253-262.

Živković, D. (2000), Teorija i metodika korektivne gimnastike [Theory and methodology of corrective gymnastics], SIA, Niš,.

Živković, D. (2009), Osnove kineziologije sa elementima kliničke kineziologije [An introduction to kinesiology with elements of clinical kinesiology]. Fakultet sporta i fizičkog vaspitanja, Niš.

Corresponding author:

Jorgic Bojan, $\mathrm{PhD}$, Assistant Professor,

Boulevard Z. Djindjica 73/7, 18000 Niš, Serbia

Telephone number: +381605537118

Email: bojanjorgic@yahoo.com 